CHAPTER 3

\title{
Poems on the Threshold: Neo-Latin carmina liminaria
}

\author{
Harm-Jan van Dam
}

\section{Introduction}

Imagine someone about four hundred years ago picking up a new Latin book, for instance the fourth edition of Daniel Heinsius' poetry, published in Leiden, shown at the end of this paper. It dates from 1613, as the colophon at the end of the book states. Readers enter the book through the frontispiece or main entrance, with its promises of sublime poetry given by the crowning of Pegasus, and of a text so much more correct and complete according to the inscription (emendata locis infinitis \& aucta) that it would be better to throw away their earlier editions. The entrance draws the reader inside to the next page where he may learn the book's contents (indicem ... aversa indicat pagina). That index is followed first by a prose Dedicatio addressed to one of the Governors of Leiden University, then by a poem in six elegiac distichs on Heinsius' Elegies by Joseph Scaliger, a letter by Hugo Grotius ending with seven distichs, and a Greek poem of sixteen distichs by Heinsius' colleague Petrus Cunaeus. Finally Heinsius devotes six pages to an Address Amico lectori. Then, stepping across the threshold, the reader at last enters the house itself, the first book of the Elegies. ${ }^{1}$

Many, if not most, early modern books begin like this, with various preliminary matter in prose and especially in poetry. Nevertheless, not much has been written on poems preceding the main text of books. ${ }^{2}$ They are often designated

1 Respectively pp. [ $\left.{ }^{*} \mathrm{v}\right]$ index, ${ }^{*}$ iir-[ ${ }^{*}$ viiir] dedication to Corn. van der Mylen, [viiiv] poem by Scaliger, ${ }^{* *} \mathrm{r}-\mathrm{v}$ poem by Grotius, ${ }^{* *}$ iir-v poem by Cunaeus, ${ }^{* * i i i r-v v}$ Amico lectori. For a full bibliographic description, see R. Breugelmans, Fac et spera:Joannes Maire, publisher, printer and bookseller in Leiden 1603-1657: a bibliography of his publications (Houten 2003), 114-5. Cunaeus (Van der Cun, 1586-1638) was from Flushing, where Heinsius grew up. In 1614 he succeeded Heinsius as Professor Politices.

2 See above all two publications by J.W. Binns: his fundamental Intellectual Culture in Elizabethan and Jacobean England. The Latin Writings of the Age (Leeds, 1990), 165-71, and "Printing and paratext in Sixteenth-Century England: The Oxford and Cambridge Presses", Cahiers Élisabéthains 50 (1996), 1-10. See also F.B. Williams, Index of Dedications and Commendatory Verses in English Books before 1641 (London, 1962), Frieder von Ammon

(C) KONINKLIJKE BRILL NV, LEIDEN, 2015 | DOI 10.1163/9789004289185_004 
more or less depreciatively as 'verse' or even 'puffs', but I prefer the term poetry. ${ }^{3}$ In the following I will call it 'liminary poetry' or 'threshold poetry' and also 'liminal poetry', as I shall explain. French (poésies liminaires) and Dutch (drempeldichten: threshold poems) have the same term. In late Latin and Neo-Latin the word liminaris in this sense of 'at the outset', 'on the threshold' occurs once or twice. ${ }^{4}$ Other terms in use refer to the different functions this kind of poetry may have, such as: 'laudatory verse', Ehrungsgedicht, ${ }^{5}$ since it praises the author and his work; or 'commendatory poetry' for commending author and book to the public or to a mecenas; or 'dedicatory poetry', Widmungsgedicht because it dedicates the book to someone. These different but not mutually exclusive functions refer to different agents and publics: praising is done by others than the author himself such as friends, publishers, booksellers, whereas in general it is the author who dedicates his work; both parties may commend a text, driven by ambition, hope of financial gain, friendship or other motives.

In this paper I will discuss Neo-Latin (and some Greek) liminary poetry in a broad sense. This means that I will not restrict myself to poetry of praise, or to poetry that is composed by those other than the author and that precedes the text, as in Heinsius' 1613 Poemata - although that remains the most important kind of liminary poetry - but will include all 'intrusive' poetry, whatever its function or position in a book is. One purpose is to show how great the variety in liminary poetry may be, both in kind and in function, with some attempt to distinguish between different types. First some attention will be paid to the literary status of these poems, to their ancient roots, and to some early and

Einleitung in Die Pluralisierung des Paratextes in der frühen Neuzeit. Theorie, Formen, Funktionen, ed. Frieder von Ammon \& Herfried Vögel (Berlin, 2008), Harm-Jan van Dam, "Taking occasion by the forelock. Dutch poets and appropriation of occasional poems", in Latinitas Perennis Vol. II Appropriation and Latin Literature, ed. Yannick Maes a.o. (Leiden, 2009), 95-127, Harm-Jan van Dam, "Liminary poetry in Latin and Dutch, the case of Pieter Bor's Nederlantsche Oorloghen”, in Dynamics of Neo-Latin and the Vernacular. Language and Poetics, Translation and Transfer, ed. Tom Deneire (Leiden, 2014; in press), 45-63.

3 'metrical puffs': Williams xi, cf. Binns 1996, 9: 'puffs'.

4 See Augustine Epist. 40.2 to Jerome (A.D. 397):... quae sit eius inscriptio, nescimus adhuc; non enim hoc codex ipse, ut adsolet, in liminari pagina praetendebat, "the name of which I do not yet know, for the manuscript itself had not the title written, as is customary, on the first page", and Jerome's answer Epist. 112.3. There are perhaps also a few medieval occurrences. For Neolatin, see Vadianus epist. 26 p. 207 "Mox ubi e quodam liminari epistolio Hieronymum quendam, cognomento Vadium, literarum studiosum in Italia agere casu intellexi, ne cognomines fieremus, adiecta syllaba Vadianus factus sum": J. Ramminger, cognominis, in ders., Neulateinische Wortliste. Ein Wörterbuch des Lateinischen von Petrarca bis 1700, www.neulatein .de/words/1/ooo253.htm (used on 21.07.2014).

5 Von Ammon, Einleitung (see above n. 3). 
rare forms of such poetry outside the 'real' text. Then I shall examine the liminary poem from several angles basing myself mainly on material from Holland dating from 1550-1630, the period which I know best. I hope that from this relatively late and fully developed form of the liminary poem more general conclusions about the nature and characteristics of liminary poetry may be drawn, although this is an exploration rather than a finished investigation.

\section{Occasional Poetry. Paratexts. Liminality}

Liminary poetry is a subspecies of occasional poetry, perhaps one of its least exciting forms, since it is unrelated to the big events in life: birth, marriage, death; besides this, its public is restricted to a select peer-group of writers and scholars - say Neo-Latinists, people who consider publication of their book a major event. Poetry for the occasion is a genre in which literature and history intersect, and these liminary poems may offer an insight into the conditions under which literature is produced, received, and functions: we find historical data or material for reconstructing social networks; we may discover publishers' policies or authors' ways of self-presentation. As well as this, these poems are also literary texts: their threshold position confers a particular standing upon them; intertextuality, often with ancient literature, plays a part; and as works of art they are part of the literary system as a whole. All these aspects represent different perspectives, not, of course, mutually exclusive properties. ${ }^{6}$

From another point of view liminary poetry is also a subspecies of paratext, as defined in Gérard Genette's epochal book of twenty-five years ago: "a certain number of verbal or other productions... surrounding and extending (the text)", ${ }^{7}$ such as prefaces, dedications, page-numbers, colophons, indices etcetera. However, Genette's stimulating book focuses on nineteenth-century

6 On occasional poetry see e.g. Aline Smeesters, Aux rives de la lumière. La poésie de la naissance chez les auteurs néo-latins des anciens Pays-Bas entre la fin du XV siècle et le milieu du XVII ${ }^{e}$ siècle (Louvain, 2011), 1-13, my own "Taking occasion, Tom Deneire, "Neo-Latin and Vernacular Poetics of Self-Fashioning in Dutch Occasional Poetry $\left(1635^{-1640)}\right.$ " in Dynamics of Neo-Latin (both in n. 3), all with further literature; also W. Segebrecht, Das Gelegenheitsgedicht. Ein Beitrag zur Geschichte und Poetik der deutschen Lyrik (Stuttgart, 1977), E.K. Grootes, “'Ter begraefenisse van den hooghgeleerden heere, Peter Schryver'. Iets over de ontstaanssituatie van gelegenheidspoëzie in de zeventiende eeuw", Jaarboek van de Maatschappij der Nederlandse Letterkunde, 1996-97 (1997), 3-16. Segebrecht excluded the liminary poem from his material precisely because its occasion is too insignificant.

7 Gérard Genette, Seuils, (Paris, 1987), Paratexts, English translation by Jane E. Lewin (Cambridge, 1997) there 1. Genette coined the term paratexte in his 1982 Palimpsestes, 9. 
and twentieth-century French literature; moreover, it ignores the liminary poem, a striking omission in a book titled Seuils ('Thresholds'). It is evident that paratexts are vital to texts: they steer readers' interpretation. Authors, publishers and readers negotiate over texts by means of paratexts. As Genette put it: "Le texte sans son paratexte est... comme un éléphant sans son cornac, puissance infirme"8 (the text without its paratext is like an elephant without its mahout, weak strength). In the last decades literature on paratexts has expanded, sometimes taking into account early modern practice, in a few cases including liminary poetry, but most often focusing on prose and the paratextual dedicatio. ${ }^{9}$

Apart from 'occasional' and 'paratextual' I would like to use the term 'liminal' to characterise verbal paratexts, and particularly paratextual poetry or liminary poetry, borrowing a notion from literary theory, in its turn loosely based on anthropology. In his famous book Les rites de Passage (1909) the French folklorist and anthropologist Arnold van Gennep divided ritual into three stages, preliminarity, liminarity and postliminarity, that is to say separation - transition integration. The best-known example of such rituals was the initiation of boys in many non-western societies: first they were separated from their family, then they spent a transitional period outside society, without rules or with very specific rules only, in a peer-group, finally they crossed over and were integrated into the society of adult men. The terminology in itself refers to the many religious beliefs and taboos surrounding this threshold, limen in Roman religion, as in many other cultures. ${ }^{10}$ In the Nineteen-sixties Van Gennep's ideas were

$8 \quad$ Seuils 376.

9 See e.g. François Rigolot, "Prolégomènes à une étude du statut de l'appareil liminaire des textes littéraires", L'esprit créateur, 27.3 (1987), 7-18, Adrian Armstrong, Technique and Technology: Script, Print and Poetry in France 1470-1550 (Oxford, 2000), Demmy Verbeke, Ad musicae patronos. Latijnse dedicaties en inleidende teksten in motettenbundels van componisten uit de Nederlanden (ca. 1550-ca. 160o) (Diss. Leuven, 2005) 4 vols. (https:// lirias.kuleuven.be/bitstream/1979/16o/2/admusicaepatronos.pdf), Guyda Armstrong, "Paratexts and their functions in seventeenth-century English decamerons", Modern language Review 102 (2007), 40-57, Cui dono lepidum novum libellum. Dedicating Latin works and motets in the sixteenth century: Proceedings of the International conference held at the Academia Belgica, Rome, 18-20 August 2005, ed. Ignace Bossuyt a.o. (Leuven, 2008), especially Mary S. Lewis, Introduction, 1-11 there, also the articles bij Enenkel and SchmidtBeste there, Bettina Wagner, "An der Wiege des Paratexts. Formen der Kommunikation zwischen Druckern, Herausgebern und Lesern im 15. Jahrhundert" in Von Ammon 2008 (see above n. 3), 133-55. See also below.

$10 \quad$ For Rome, see e.g. Cicero De Divinatione 2.84 pedis offensio, touching the threshold, as a bad omen, Catullus 61.159, Ovid Tristia 1.3.55 etcetera. Four times did the Wooden Horse 
rediscovered and transposed from tribal communities to modern society by the Scottish anthropologist Victor Turner. He focused on the liminary stage as a period of lawlessness and inversion of norms, an interspace in which people are searching for an identity and transgressing boundaries. For Turner the limen is primarily a boundary line. ${ }^{11}$ Since Turner the concept has been further developed and extended in the social sciences, and 'liminality' as referring to a state where "social hierarchies may be reversed or temporarily dissolved, continuity of tradition may become uncertain, and future outcomes once taken for granted may be thrown into doubt" is now sometimes considered to be a master concept. ${ }^{12}$

In literary theory a notion of liminal (rather than liminary) poetics was developed from the Nineteen-eighties onward. Genres, characters, themes or style can be viewed as liminal, for instance crossover literature, transvestite or impersonating heroes, or formulaic language. Here, unlike Turner and his followers, the limen is mostly seen as a zone again rather than a line or boundary: "the threshold is a territory or provides entry into one", states Manuel Aguirre, a leading exponent of liminality in literature. I agree that it is useful to draw a clear distinction between the notions of liminality and that of marginality with which it is often combined or considered as synonymous: the margin presupposes a centre, is agonistic and brings in notions of transgression, whereas the limen is neutral and opens up new worlds. ${ }^{13}$ 'Liminal' then refers to the

halt on the threshold of Troy in Vergil's Aeneid 2.242, see also Tibullus 1.3.19 with the commentary by K.F. Smith.

11 A. van Gennep Les rites de passage: Étude systématique des rites de la porte et du seuil, de l'hospitalité, de l'adoption, de la grossesse et de l'accouchement, de la naissance, de l'enfance, de la puberté, de l'initiation, de l'ordination, du couronnement, des fiançailles et du mariage, des funérailles, des saisons, etc. (Paris, 1909), Victor Turner, The Forest of Symbols. Aspects of Ndembu Ritual (Ithaca, 1967).

12 Wikipedia Liminality, with extensive bibliography, last consulted 22.07.2014. The quotation there is from Bjørn Thomassen in Agnes Horvath a.o., The Uses and Meanings of Liminality (International Political Anthropology 2009), 51, see also Arpad Szakolczai, Liminality and Experience: Structuring transitory situations and transformative events (International Political Anthropology 2009).

13 Liminality as a literary concept is the subject of a research project Threshold and Text, funded by the Spanish Ministry of Science. It results a.o. in the series $S L L$ Studies in Liminality and Literature (Madrid), which started in 2000 with Margins and Thresholds. An enquiry into the concept of Liminality in text, ed. M. Aguirre a.o. The quotation is in his Introduction there, cf. Isabel Soto in $S L L 2$ (2000), 15. The contrast between marginal and liminal is brought out well in Mihai I. Spariosu, The wreath of wild olive: play, liminality and the study of literature (New York, 2007), 38 ff. In the Nineteen-twenties Walter Benjamin had already noted "Die Schwelle ist ganz scharf von der Grenze zu scheiden, Schwelle ist eine Zone": 
intermediacy of a text: the threshold is a zone halfway between the outside world and the world of the book, a Forest between the Worlds or Platform $93 / 4$. Here the reader first becomes acquainted with the author, his friends and his work by way of these liminary poems which advertise, summarize, commend, praise, network, and (re)present. It is here that the reader's expectations are shaped and he is put into the right mood to enter the text. It is an interface between world and text. ${ }^{14}$ The concept of liminality fits with early modern ideas about books: title-pages or frontispieces often show architectural elements, as we have noted in Heinsius' Poemata at the outset, and were also called 'arches'; in prefaces the book is called a theatre or building with doors and entrances. Jean Lemaire called his book ung ediffice and Francis Bacon compared the liminary work of orations to Vestibula, Posticae, Anti-Camerae, Re-Camerae, Transitus \&c. ${ }^{15}$ This liminality is characteristic of all paratextual verse, as long as it keeps its original position in a book. It includes all functions of the threshold poem such as praising, dedicating, etcetera, and the concept opens, I think, a useful perspective on our poetry in all its variety, which leads the reader from the outside world into that of the text or sometimes shepherds him out at the end.

Das Passagen-Werk: Gesammelte Schriften V 1, ed. Rolf Tiedemann (Frankfurt am Main, 1991), 618. Marginality, transgression and cognate concepts remain useful for literary theory in their own right, of course.

14 “Cet interface entre l'oeuvre et le monde qu'est le liminaire": Arnaud Laimé, La poétique de Nicolas Petit, (Thèse Paris IV, 2011) 2 vols, cf. vol. 2, 8-9. The same term is used by Aguirre a.o. and Spariosu (see above n. 14) 38 .

15 On Jean Lemaire's Temple d' Honneur et de Vertus (1504), "ung ediffice sumptueux a merveilles", see Armstrong (see above n. 10), 126-7 (the quotation on 126). Francis Bacon $D e$ dignitate et augmentis scientiarum (Opera London, 1623) 2v4": "Illae autem sunt, veluti Vestibula, Posticae, Anti-Camerae, Re-Camerae, Transitus \&c. Orationis, quae indiscriminatim omnibus subiectis competere possint... Quemadmodum enim in aedificiis Plurimum facit \& ad Voluptatum \& ad Usum, ut Frontispicia, Gradus, Ostia, Fenestrae, Aditus, Transitus \& huiusmodi commoda distribuantur, eodem modo etiam in Oratione". On arches, see Kevin Sharpe, Reading Revolutions. The politics of reading in early modern England (Yale, 2000), 27 ff., also e.g. Antoine Furetière: "la face et principale entrée d'un grand batîment qui se présente de front aux yeux des spectateurs" in Louis Marin, "les enjeux d'un frontispiece", L'Esprit Créateur (see above n. 10), 49, William H. Sherman, “On the threshold. Architecture, paratext and early print culture" in Agent of Change... ed. S.A. Baron a.o. (Amherst / Boston, 2007), 67-81. 


\section{Liminary Poems: Ancient Examples, Manuscripts and Early Books}

"Printing gave a great boost to paratext": ${ }^{16}$ paratexts chiefly belong to the culture of the printed book, although some liminary poetry is also found in manuscripts, for instance in musical work and French manuscript works by the rhétoriqueurs. ${ }^{17}$ When large-scale reproduction of texts became easy, the new profession of publishers, and authors as well, had to devise fresh strategies of communication with hundreds of unknown readers instead of offering one manuscript to a patron and his circle. However, liminary texts have roots that reach back to the manuscript culture of antiquity: dedication, to a mecenas or to a fellow aristocrat, in the form of a letter or preface occurred from the third century вс onwards. The place for dedicating a book of poetry is its opening poem; mentioning the name of the addressee there means dedication of the whole book. Thus Horace's Odes opens with the name of Maecenas, who is addressed at the opening of Horace's first book of Epistles as well. Catullus' first poem is addressed to Cornelius Nepos, Propertius' to Tullus, and so on. All these dedications, however, occur within the main text not outside it. Similarly, the end of an ancient poetry book, and sometimes its beginning, may take the form of a seal, the so-called sphragis: the poet addresses his own book and / or presents himself and his work. Thus for instance the last poem of Horace Odes 1-3 (published as a whole): exegi monumentum I have erected a monument, or the opening of Ovid's Tristia, where the exiled poet sends his book to Rome as his substitute. ${ }^{18}$

All these opening and closing poems were popular models for Neo-Latin liminary poetry. In other cases, however, there are traces of dedicatory or introductory verse in antiquity outside the main text too: in some manuscripts and in most early editions Vergil's Aeneid opens with or is preceded by four lines, non-epical in style, in which the poet presented himself and his literary career, the so-called rota Vergiliana, the development from bucolic poet to epic

16 Binns 1996, 5 (see above n. 3).

17 A few musical manuscripts written for Pope Paul III have short poems in the colophon, addressing the reader and extolling the Pope's virtues, although in theory the only readers would have been the Pope and a singer: see Schmidt-Beste (see above n. 10) 93-4, 105-08 with a few more musical examples, also Williams Index (see above n. 3) ix, Cynthia J. Brown "Poètes, mécènes et imprimeurs à la fin du Moyen Âge français: une crise d'autorité" in Pratique de la culture écrite en France au XVI ${ }^{e}$ siècle, ed. Monique Ornato a.o. (Louvainla-Neuve, 1995), 423-40.

18 Also the last poem of Horace's Epistles 1, Sidonius Carmina 24, the last poem of Ovid's Amores and many more. See, also for the following, my own "Vobis pagina nostra dedicatur. Dedication in Classical Antiquity” in Cui dono (see above n. 10), 13-32. 
poet by way of didactic poet: Ille ego, qui quondam gracili modulatus avena / carmen, et egressus silvis vicina coegi, / ut quamvis avido parerent arva colono, / gratum opus agricolis, at nunc horrentia Martis / (Arma virumque cano).19 Ovid's three books of Amores are similarly preceded by a four-line epigram in which they themselves state that they were formerly five books, but are now three, which makes for an easier read. ${ }^{20}$ The volume known as Priapea, the most obscene ancient volume of poetry in existence, composed around $100 \mathrm{AD}$, has an opening poem warning the reader who is just starting out: "this will be a book about Priapus, which may make you frown: close it or be prepared."21 It has been argued that this poem may well have been written on the outside of the book-scroll, a jesting caveat to be read before entering; ${ }^{22}$ the epigram on Ovid's Amores may be interpreted as a similar heading. Another way of introducing poems is employed by Claudian (around $400 \mathrm{AD}$ ): several of his long hexameter poems are preceded by shorter poems in different metres. Thus his hexameter Epithalamium for the Emperor Honorius and his bride Maria is preceded by eleven elegiac distichs. They sing of the birth of Achilles with many allusions to Catullus' Carmen 64; like liminal poetry this introductory poem puts the reader in the right frame of mind, intertextually enticing him to view the Emperor in the following Epithalamium as a second Achilles. ${ }^{23}$ In manuscripts of Ausonius (around 370) several introductory pieces are found, probably meant to open the complete collection. Some or most of the following were printed at the beginning of Renaissance editions: a letter by the Emperor Theodosius the Great asking Ausonius politely not to cheat him of reading his works, an opening poem by Ausonius in reaction to this letter; a verse-letter in which Ausonius introduces himself - a sphragis -, asking for the reader's favour; a four-line poem to the highly-placed official Syagrius, which

19 The lines first occur in a ninth-century manuscript and are excluded from editions of the Aeneid by practically all editors of the last two centuries.

20 Qui modo Nasonis fueramus quinque libelli, / tres sumus; hoc illi praetulit auctor opus. / ut iam nulla tibi nos sit legisse voluptas, / at levior demptis poena duobus erit.

21 Carminis incompti lusus lecture procaces / conveniens Latio pone supercilium / . . / aut igitur tunicam parti praetende tegendae / aut quibus hanc oculis aspicis, ista lege!

22 Vinzenz Buchheit, Studien zum Corpus Priapeorum (München, 1962). Similar title poems may also have existed for Greek Hellenistic works such as Antimachus' Lyde and Erinna's Distaff.

23 For similar examples, see In Rufinum I, In Eutropium II, Both books of Claudian's Rape of Proserpine are also preceded by an introductory poem, the second of which is a dedication as well. Alan Cameron, "Pap. Ant. III 115 and the Iambic prologue in Late Greek Poetry", Classical Quarterly 20 (1970), 119-29 claims that iambic prefaces of hexametric poems are "standard if not universal practice" in the fourth to sixth century (119). 
is both a dedication and a preface; and a dedicatory poem to his countryman Drepanius that opens by quoting the first line of Catullus' opening poem. ${ }^{24}$ Taken together, these liminary pieces advertised the modest poet and his successful career, his connections in high places, the love for letters of Syagrius, the benignity and cultural interest of the emperor, and, of course, the literary competence of Ausonius himself, in short his cultural capital. ${ }^{25}$ So all kinds of liminary strategies were adopted in antiquity that laid the foundation for $\mathrm{Neo}-$ Latin liminary poetry; the main difference seems to be the lack of commendatory verse by others in the manuscript culture of antiquity.

In the earliest printed books publishers and authors are still looking for ways to present their production and themselves; and the immediacy and memorability of poetry commended it for that role. The colophon at the end of the book with information about place, year and publisher caught on in around the 1470s; it is the place where early liminal poetry is most often found. The earliest example is the so-called Mainzer Catholicon, the 1460 edition of the Thirteenth-century lexicon compiled by Ioannes Balbus; its colophon bears a four-line hexameter poem thanking God for making possible this publication: Hinc tibi sancte pater nato cum flamine sacro / Laus et honor domino trino tribuatur et uno...(Hence to Thee, Holy Father, and to the Son, with the Sacred Spirit, / Praise and glory be rendered, the threefold Lord and One). ${ }^{26}$ In England the oldest example is Chaucer's epitaph by the poet laureate Stephanus Surigonus in the colophon of Chaucer's translation of Boethius' De consolatione philosophiae (c. 1478). ${ }^{27}$ Such poems form a gentle slope for readers to slide from the poet's text back to the outside world while meditating

24 In the modern standard edition, The works of Ausonius, ed., introd. and commentary by R.P.H. Green (Oxford, 1991) they take first place as Praefationes Variae, in this order: sphragis, Syagrio, Theodosio, Drepanio, with the addition of a fifth poem addressed to his paper (and without the letter from Theodosius). According to Green the first two and perhaps the third may at one time have introduced the collection, the other two may have introduced (lost) parts of it. The letter from the Emperor and its reply seem to open the collection in all early editions; the edition by Scaliger (Lyon, 1575) opens with: letter, reply, Syagrio, Drepanio.

25 More examples abound: Ausonius preceded his cycle of poems for the dead slave-girl Bissula with a dedicatory prose-letter and a prefatory poem, both to his friend Paulus. The scheme of Ausonius' Parentalia, poems for All Souls day, is identical, see Green 132-4. Cf. also Sidonius carmina $14-15,22$.

26 Hinc tibi sancte pater nato cum flamine sacro / Laus et honor domino trino tribuatur et uno / Ecclesie laude libro hoc catholice plaude / Qui laudare piam semper non linque mariam. Deo Gracias. See Wagner, “An der Wiege.” (see above n. 10). 
on God's omnipotence or man's mortality. After 1467, when they moved from Subiaco to Rome, the printers Sweynheim and Pannartz had colophons with advertising poetry telling the curious reader that these distinguished books were printed by two men with harsh-sounding, funny German names. ${ }^{28}$ In 1475 the Italian scholar Domizio Calderini ended his edition with a commentary of Statius with a self-conscious six-line poem to the reader, beginning with Sic mihi perpetuae contingant murmura laudis / Et bona post funus hora superstes eat ("let the clamour of eternal fame be my share and the good time be prolonged after my death"). ${ }^{29}$ His claim to fame, he states, is having composed his book purely for the good of mankind: nostros cupio multis prodesse libellos, 'I wish that my books will be of use to many men'. In this way he presents himself as a benefactor at the moment of taking leave of his reader.

Generally speaking, information moved from colophon to title-page in the course of time; in two editions of the Roman grammarian Priscianus for instance, that of 1485 gives all the information in the colophon, whereas that of 1495 bears the advertising elements on the title-page. ${ }^{30}$ The role of the title-page only fully blossomed in the sixteenth century, but there are a very few early examples of title-pages with information in verse: the oldest one is Johann Müller of Königsberg's Calendarium of 1476 printed in Venice. Six distichs surrounded by flowery ornaments combine advertising (aureus hic liber est is the opening), with a description of the contents; they mention the author: Ioannes . . regio de monte and the place of printing. ${ }^{31}$ Finally the printers are indicated: per illos / Inferius quorum nomina picta loco, and indeed inferius, underneath, three names follow printed in red. ${ }^{32}$ This poem functions as an elaborate blurb; similar ones are frequent in German vernacular books of

28 "Aspicis illustris lector quicunque libellos, / si cupis artificum nomina nosse: lege./ Aspera ridebis cognomina Teuthona: forsan / mitiget ars musis inscia verba virum. / Conradus Sweynheym Arnoldus Pannartzque magistri / Rome impresserunt talia multa simul./ Petrus cum fratre Francisco Maximus ambo / Huic opem aptatam contribuere domum.": for instance in the editions of Lactantius 1470, Cicero 1471, Silius Italicus 1471.

Domitius ad lectorem Sic mihi perpetuae contingant murmura laudis / Et bona post funus hora superstes eat. / Ut nostros cupio multis prodesse libellos / Famaque non nullo tincta cruore placet. / Me legat invitus nemo, non scripsimus illi: / Huic scripta est si quem pagina nostra iuvat.

3o Wagner, "An der Wiege..." (see above n. 10).

31 Also: "hunc emat astrologus". Author and place: "Hoc Ioannes opus regio de monte probatum / composuit ... Veneta impressum ... in tellure."

32 An Italian version, which appeared in the same year, and a German one two years later, display free translations of the same poem: thus the Italian one counts seventeen lines, ending with "I nomi dei impressori / Son qui da basso in rossi colori". For the whole, see 
the sixteenth century. Most of them keep to verse like "Buy and be confident / You won't repent" (Kauf mich mit gutem Treuen / Es wird euch wahrlich nicht gereuen), but religious conflicts may also be fought out on these title pages. Thus the title-page of a book called About the Holy Year 1525 reads: "this book speaks publicly / of the two-fold Holy Year: / the one is our Lord Jesus Christ's, / the other the Pope's fair". ${ }^{33}$ The title-page of an early book issued by Erasmus in Paris in 1497 seeks publicity for the editor rather than for the author or publisher. It the poetry of his friend Willem Hermans, Sylva Odarum; on opening the book the French reader found the first poem by Erasmus to appear in print and quite an early example of liminal poetry too - where Erasmus claims that in Hermans' poetry everything is pure (nihil inquinatum) and honest, and at the same time presents himself as a promising humanist poet. ${ }^{34}$

\section{Liminal Poetry Composed in Holland: General}

Having now covered these more generic and genetic remarks I will focus on liminal poetry composed by Dutch Latin poets of the late sixteenth and early seventeenth centuries, basing myself on several hundreds of poems. ${ }^{35}$ This poetry belongs in the academic environment of the new University at Leiden, founded in 1575 , which offered the ideal climate for all kinds of occasional

Margaret M. Smith, The Title-Page, its early development, 1460-1510 (London, 2000) 43 and 107 , with a few other examples.

Dies Büchlein sagt ganz offenbar / Von zwiefältigem Jubeljahr, / Das ein des Herren Jesu Christ / Das ander des Papstes Jahrmarkt ist, Von dem Jubeljahr genannt das guldin Jahr, 1525. See K. Schottenloher, "Titelreime mit Buchanpreisungen aus der Frühdruckszeit. Ein Beitrag zur Geschichte des Titelblatts", Börsenblatt für den deutschen Buchhandel 94 (33), 09.II.1927, 1-4.

34 Huc, siquem pia, si pudica musa / Delectat: nihil hic vel inquinatum / Vel quod melle nocens tegat venenum. / CHRISTVM tota sonat chelis Guilelmi: Guielermi Hermani Goudensis Theologi ac Poetae clarissimi Sylva Odarum, Parisiis 1497, published by Guy Marchant and by Denys Roce each with his own printer's mark, see Sandra Hindman in Printing the written Word: The social History of Books ca. 1450-1420, ed. Sandra Hindman (Ithaca/London, 1991), 68 ff., esp. 74 ff. On Erasmus' poem, see the standard edition by Harry Vredeveld (Amsterdam, 1995) n. 30 p. 151; on Erasmus and Hermans: Harm-Jan van Dam, "Batavian Wood: Silvae in the Low Countries from 1500-1650", in La silve. Histoire d'une écriture libérée en Europe de l'antiquité au XVIII ${ }^{e}$ siècle, ed. Perrine Galand \& Sylvie Laigneau-Fontaine (Turnhout, 2013), 600-24, there 610-1.

Around 200 poems examined closely and perhaps another 200 studied less thoroughly. 
verse, certainly also poems for books, just as every academic circle does. ${ }^{36}$ In Leiden we meet scholars such as Ianus Dousa (Jan van der Does, 1545-1604), founder of the university, Iustus Lipsius (Joost Lips, 1547-1606, in Leiden until 1591), Iosephus Scaliger considered by many contemporaries as the greatest scholar of the age (della Scala 1540-1609, in Leiden from 1593), the Hellenists Bonaventura Vulcanius (De Smedt, 1538-1614), Daniel Heinsius (Heyns, 15801655) and Johannes Meursius (Jan van Meurs, 1579-1639), the independent scholars Hugo Grotius (Hugo de Groot, 1583-1645) and Petrus Scriverius (Pieter Schrijver, 1576-1660), scholar-poets such as Dominicus Baudius (Dominique Baudier, 1561-1613), and many others from outside the Low Countries.

First, let us now look at a few figures: what metres did poets use? As one would expect, most poems are in elegiac distichs, around $65 \%$ of my material, $10 \%$ are in hexameters and another $10 \%$ in hendecasyllables, $5 \%$ in iambic senarii and somewhat less than that in alcaic stanzas. Anyone who had finished the Latin school would have been able to write in all of those metres, though perhaps not in such flowing verse as most of our poets. Only a few ambitious poets use more far-fetched forms for their liminal poetry: in the Inscriptiones of Ianus Gruterus (1603) 'Cunradus Schoppius ... poeta laureatus', the Heidelberg professor Conrad Schoppius, used the rare fourth archilochean of Horace's Odes 1.4. ${ }^{37}$ Joseph Scaliger wrote a so-called Sotadean for the young Grotius, a complicated metre found in archaic Latin poetry, a field in which Scaliger considered himself an expert. ${ }^{38}$ The number of poems received from friends varies enormously, four to six in one book seems a good score. However, a solid geographical scholar like Johannes de Laet has only one commendatory poem in his magnificent folio Description of the West Indies, albeit one by the famous Daniel Heinsius, ${ }^{39}$ and long-time professor Vulcanius published several books with one poem or even without any contributions by others. In his case most (but not all) publications of his first ten years in Leiden (1584-94) were well-stocked with poems, ten each in his editions of Callimachus (1584)

36 Some other examples are the Collège Montaigu in Paris in the period $1500-1520$, see Laimé Nicolas Petit (see above n. 15) 2, 15-80, Uppsala University around 1630, see Anika Ström, Lachrymae Catharinae (Stockholm 1994), Tartu/Dorpat University 1630-6o, see Kristi Viiding, Die Dichtung neulateinischer propemptika an der Academia Gustaviana (Dorpatensis) in den Jahren 1632-1656 (Tartu, 2002). For England see the data given by Binns, Intellectual Culture 165-71, also Binns 1996 (see above n. 3).

37 F. e2r, number 3. On Gruter's book and its liminary verse, see also below.

38 In Grotius' edition of Martianus Capella (Leiden, 1599) *2r-v.

39 Novus orbis seu descriptionis Indiae occidentalis libri XVIII (Leiden, 1633), the poem on $\left[{ }^{*} 4 \mathrm{r}\right]$. 
and Agathias (1594), but after 1595 near silence reigns. ${ }^{40}$ Almost always authors write more poems for the books of others than they receive even if they are as productive as Vulcanius: in 21 books by him we find 29 threshold poems by others (and seven by himself), while he composed at least $5^{\circ}$ poems for others. ${ }^{41}$ On the receiving side Ianus Gruterus (Jan de Gruytere, 1560-1627) is one of the champions. His 1602 Inscriptiones is a splendid folio and a landmark in epigraphy and was destined to hold the field until the appearance of the great nineteenth-century Corpora, and it was composed by someone with a central role in the Republic of Letters as a Heidelberg professor and librarian of the famous Bibliotheca Palatina. The book received 44 poems by 42 poets. ${ }^{42}$ From the difference between the Inscriptiones and De Laet's Descriptio, or between some books by Vulcanius and others, we conclude that apparently specific circumstances are decisive for the number of poems, which need to be studied case by case. The same probably applies to the length of poems. The average poem in distichs has 16 lines, hexameter poems tend to be long, often over a hundred lines (in my sample only 3 of them have less than 25 lines); two lengthy poems were composed by Hugo Grotius, an ambitious man indeed. Long poems in the great style have a double function, of course, they honour the addressee and advertise the author.

The publisher or perhaps the author, or both, clearly organise commendatory poems within books: in virtually every work containing a poem by Joseph Scaliger written in his Leiden years, that is in $3^{1}$ out of his 38 poems for books, his poem comes first. Then follow, almost always in this order, Vulcanius, Heinsius, other distinguished professors, then Grotius, Scriverius, others. Thus the publisher attracted attention with the most famous scholar of the period and satisfied academic precedence, while the author advertised his connection to the great Scaliger, and readers met a celebrity on opening the book.

40 There is one poem in Vulcanius' De literis et lingua Getarum (Leiden, 1597), the Thesaurus utriusque linguae (ibid. 1600) and his Tres fratres Belgicae by Vulcanius himself (ibid. 1612); there are no poems in his editions of Constantinus Porphyrogenneta, (Leiden, 1588), Nilus (ibid. 1595), Iornandes (ibid. 1597), Apuleius (ibid. 1600), Cyrillus (ibid. 1605). For a list of Vulcanius' editions, see Bonaventura Vulcanius, Works and Networks, Bruges 1538-Leiden 1614), ed. Hélène Cazes (Leiden, 2010), p. 67. A survey of his Greek editions by Thomas Conley is on pp. $337-50$ there; see especially Alfons Dewitte, "Bonaventura Vulcanius. A bibliographic survey of the editions 1575-1612", Lias 8 (1981) 189-201.

41 See Harm-Jan van Dam, “'The honour of letters': Bonaventura Vulcanius, scholar and poet", in Bonaventura Vulcanius $47-68$, with a survey of 42 liminary poems composed by Vulcanius in one manuscript, Leiden Cod. Vulc. 103, there 68.

42 Inscriptiones antiquae totius orbis Romani, in corpus absolutissimum redactae Heidelberg 1602 . 
In one case only did Scaliger have to renounce his first position, in the homage for the Inscriptiones of Ianus Gruter. This is opened by Paulus Melissus, who had some advantages over Scaliger in this respect: he was a poet laureate and also Gruter's predecessor as the Palatine librarian; besides he had died just before the work appeared.

Commendatory poems were obtained by authors, friends, relations and protectors, and also by publishers. The case of Elizabeth Weston, the English Latin poetess living in Bohemia, is well-known: on behalf of a second edition of her 1602 Poemata Weston's protector Von Baldhoven recruited poems from all over Europe. In a letter of November 1601, we see Daniel Heinsius exerting some pressure on Ianus Dousa to finish his poem. Heinsius argued that his own contribution and something by Scaliger were ready, but that they had to wait for Dousa's poem by order of Von Baldhoven. And it is clear that Von Baldhoven set great store by Dousa's work as seven poems by him were printed at the end of this book by a lady he had never met, some of them honouring Von Baldhoven himself. Here Dousa precedes all other poets, including Paulus Melissus. Heinsius produced one poem, and Scaliger only a letter. ${ }^{43}$ In the case of Gruterus' Inscriptiones Bonaventura Vulcanius was the Dutch broker: it is to him that Hugo Grotius sent his long poem (1601), which was 'requested on behalf of Gruter'. Grotius argued that its number of lines is so large because they could not compete with those of Vulcanius and Heinsius in pondus. ${ }^{44}$ This modesty hides great ambition: this is the longest of all the liminary poems for the Inscriptiones with its 148 senarii, and certainly ponderosum as well: it opens

43 On Weston, see Collected writings of Elizabeth Jane Weston, Donald Cheney \& Brenda M. Hosington ed. and transl., with the assistance of D.K. Money, Brenda Hosington, "Elizabeth Jane Weston and Men's Discourse of Praise" in La femme lettrée à la Renaissance: actes du colloque international = De geleerde vrouw in de Renaissance Bruxelles, 27-29 mars 1996, ed. Michel Bastiaense (Brussel, 1997), 107-18 and Donald Cheney, "Virgo Angla: the SelfFashioning of Praise", ibid. 119-28. Before the appearance of the 1602 Poemata already Von Baldhoven planned a second edition with letters and poems of praise, which appeared in 1608, as Parthenicon libri III. Dousa's poems are in Collected Writings 236-47, Scaliger's letter on 175, Heinsius' poem on 270-1, his letter on [410-1], from Ms. Burney 371 f. 37r; in it Heinsius refers to Von Baldhoven as "Silesius ille".

44 Briefwisseling van Hugo Grotius deel 1, ed. P.C. Molhuysen ('s-Gravenhage, 1928; hereafter Grotius Correspondence) number 14, p. 12, 00001601 - not 1600 as it is dated by its editor, see De dichtwerken van Hugo Grotius (The poetry of Hugo Grotius, Assen, 1977), ed. B.L. Meulenbroek 12 B 2 p. 206-7. The poem itself is in De dichtwerken $12 \mathrm{~A} 2$ pp. 130-9. Grotius calls it "postulatum nomine Gruteri carmen" and goes on: "veniam tamen amico dabis, si versus meos, quos pondere vinci a vestris necesse est, numero salten praeferre conatus sum." 
with a very elaborate imitation of Claudian's poem for the consulate of Stilicho (AD 400) and is written in a high-flown panegyric style. ${ }^{45}$ Authors themselves often requested poetry from their friends (and 'friends'): Isaac Casaubon twice asked Grotius for a threshold poem for his De rebus sacris et ecclesiasticis (1614), on condition that Grotius read the book carefully first. And if he could pressure Heinsius into composing a Greek poem for the book... Grotius complied, but there is no poem by Heinsius. ${ }^{46}$ Grotius himself provides us with a nice example of gossip in a similar case: in June 1602 he wrote to Heinsius that their friend Meursius "pesters me every day to write a panegyric." But Grotius felt uninspired, so he claimed, for anything except a (feeble) invective, for Heinsius' eyes only. The requested panegyric was perhaps destined for Meursius' Meditationes christianae, to appear in $1604 .{ }^{47}$ Some time later Grotius wrote again to Heinsius on the same subject, and in the same vein. He asked to loan a book on behalf of Meursius. He owed him a favour "because I seem to have offended the man by writing an epigram for his Meditationes christianae when I had been asked for an Encomium". Grotius had expected that his epigram, "a generous commendation," would satisfy Meursius' arrogance. ${ }^{48}$ Not so: according to Grotius, Meursius had read the poem in his presence "with puckered brows, gloomy or offended, coming to a stop almost at every

45 Claudian De consulatu Stilichonis 2.424-30, a description of a cavern where time is born and the snake devours its own tail, placed in Egypt by Grotius.

46 Grotius Correspondence 258 (p. 231) [16 or 17.IV.1613]: "De carmine iterum te appello. Semel enim frontem perfricui; sed ea lege, ut meas lucubratiunculas prius inspicias diligentius, quam scriptioni te accingas. Atque utinam maximi Heinsii Graecos versus mihi exprimere queas." For the poem and a commentary, see M. van Oosterhout, Hugo Grotius' Occasional Poetry (1609-1645) (Diss. Nijmegen, 2009) 96-101, also 21.

47 Grotius Correspondence number 31, 17.VI.1602, 23-4: "urget quotidie ut scribam Encomium." A poem by Grotius is printed in Meursius' Poemata, with 23 distichs the longest of the liminary poems [xiv-Xv]. It is published in Grotius De dichtwerken $12 \mathrm{AB}$ 3, ed. Arthur Eyffinger (Assen 1988), 376-86, with extensive commentary, and also information on Joannes Meursius (1579-1639), professor of Greek in Leiden, later of History in Sorø. Both Eyffinger and the editor of the Correspondence connect Grotius' letter with Meursius' Poemata. If this is correct, Grotius' poem would have arrived almost four months after its publication. This is not completely impossible, but I connect it to a later book of Meursius, his Meditationes christianae in Psalmum cXVI \& tres priores partes CXIX (Heidelberg, 1604) perhaps already in the making. See below.

48 Grotius Correspondence number 50, 05.I11604, 41-2: “... videor offendisse hominem, quod rogatus Encomium scribere Meditationibus Epigramma scripsi ... liberale praeconium et quo putabam ipsius quoque arrogantiae satisfieri posse." 
word ..."49 One cannot quite blame Meursius, for this epigram of six distichs is among Grotius' less inspired performances and the shortest poem he wrote for his friend.

All commendatory and dedicatory liminal poetry demonstrates prior knowledge by definition, for there, on the threshold, expert guides meet the reader who are able to explain what he is going to read or why he should do so. In fact, many liminary poems display more than superficial acquaintance with 'their' book: clearly the composers received or acquired information before the book was finished, just as Casaubon instructed Grotius. ${ }^{50}$ This becomes evident, for instance, in the case of that fourth edition of Heinsius' Poems of 1613 at the outset of this paper: its collection of Greek epigrams, the Peplus, was dedicated to Grotius. He received the libellus inscribed to him in November 1612. Grotius reacted immediately with a letter of thanks and, some time later, with a second letter containing a poem in praise of the new edition. However, his letter and poem are found in the 1613 edition, directly after the first liminal poem, which is, of course, by Scaliger. ${ }^{51}$ This demonstrates that what Grotius had received earlier must have been a partial edition, or the book in plano, for there still remained time to insert his poem in the definitive edition.

\section{Functions and Character of the Liminary Poem}

Now I would like to return to the various functions liminary poems may have, and their diverging character. The default design of a book is, as we have seen, prose dedication, prose preface to the reader and commendatory verse by

49 "fronte corrugata, tristis vel indignabundus et ad singula prope verba subsistens, quasi cum dignitate sua expenderet." The epigram, quoted there, is also found in Grotius De dichtwerken $12 \mathrm{AB}$ 4, ed. Edwin Rabbie (Assen 1992), 134-7, with commentary, and more on Meursius. Though Grotius and Heinsius repeatedly mock the arrogance of Meursius, we should not be too quick in concluding that their friendship was diminishing (nor should we agree with their disparaging comments on Meursius' work, as Rabbie ad loc. points out): Grotius wrote five liminary poems for Meursius' books, including one of 150 lines for his De Gloria (a telling title which Meursius shares with Cicero).

5o See also Binns Intellectual Culture (see above n. 3), 171.

51 See Grotius Correspondence number 250, pp. 224-5, late 1612, letter and poem; for their position in the edition, see n. 2 above, for a commentary on this poem, see Van Oosterhout (see above n. 47) pp. 78-9. For the dedication of the Peplus and Grotius' gratitude, see also letters 247 , p. 222 and 248, p. 223. Things went different with the preceding edition of Heinsius' poetry in 1610: Grotius' laudatory poem for that, composed in 1610, is found in the 1613 edition for the first time, among the Adoptiva on p. 582 (Van Oosterhout 78-9). 
friends although many variations are possible and commendatory or laudatory poems are certainly not the only important forms of liminary poetry. Some threshold poems are summaries in the first place; this function emphasizes their liminal, intermediary character: it is a comfortable way for the reader to enter a new book. The caption of Grotius' long poem for Meursius' De Gloria says "in which the main argument of the book is briefly explained;" 52 similarly a vernacular history of the Dutch Revolt in the early years $1567-73$ by Pieter Bor contains one liminal poem by Grotius, in Latin, a compendium of its argument (quae potissimam partem ... compendio complectitur). Its 276 hexameters befit the lofty subject; of course there is some praise of the author at the end, but this threshold poem primarily plays a mediating role for the superficial reader, as well as for the reader who feels more at home in Latin than in Dutch. Conversely, in the third volume of this book the title-page is preceded by a Dutch poem by Petrus Scriverius that is a summary of the book. ${ }^{53}$

This brings me to a short aside on the combination of a vernacular book and Latin poetry and the combination of Latin and vernacular in the liminary material. This is fairly common practice, as was shown by J.W. Binns for books in English with one or more Latin liminary poems, who mentions a hundred and one of them printed between $155^{\circ}$ and 1640; most of them have liminary poetry in English as well. ${ }^{54}$ As a rule, at least in England and the Low Countries, Latin works are introduced by poetry in Latin or Greek and not in the vernacular, but Dutch vernacular books may have liminary poems in Latin and in vernacular languages. ${ }^{55}$ On one level it may be argued that a function of the liminary poem is the poet's self-presentation, and that a Latin poet may advertise his skills without regard for the understanding of his poem by a vernacular author and his public and that Latin poetry increased a book's prestige and sales figures. However, it has also become clear that among educated poets the

52 "in quo potissimum argumentum libri breviter declaratur": Ioannis Meursi De Gloria liber unus ... (Leiden, 1601), p. * 5 , see Grotius De dichtwerken 1 2B 2 (see above n. 45) pp. 102-110.

53 Pieter Bor, Van de Nederlantsche Oorlogen, beroerten ende Borgerlijcke oneenicheyden ... (Utrecht, 1601), viii-xii Hugo Grotius "Silva in Annales V.C. Petri Borrhii.... The poem is also in De dichtwerken $12 \mathrm{~A}$ (see above), 185-201, commentary in $12 \mathrm{~B} 2,292-312$. Pieter Bor, Vervolch van de Neerlandsche Oorlogen, beroerten ende Borgerlijcke oneenicheyden...(Amsterdam / Leiden 1626): P.S.: "Beduydingh des Tytels, met het inhout der Boecken...." (An indication of the title and the content of the books).

54 Binns Intellectual Culture (see above n. 3) chapter 10 n. 40, 499-502. Some checking showed that perhaps not all of this poetry is really liminary, but that does not detract from the fact that the combination of English with Latin was common practice.

55 See Tom Deneire, "Neo-Latin and Vernacular Poetics..." (see above n. 7) and my own "Liminary poetry..." (see above n. 3 ). 
Latin and the vernacular language communities overlap to a large degree and that "code-switching is perfectly possible"56 Petrus Scriverius is a case in point: this learned editor of Latin texts and historical researcher, who belonged to the Scaliger circle and wrote many fluent Latin poems, composed five different poems for Bor's books, all in Dutch. ${ }^{57} \mathrm{~A}$ famous example of multilingual poetry in France is that of Louise Labé's 1555 volume of French poetry that ends with 24 poems by others, Escriz de divers poëtes à la louange de Loüze Labé Lionnoize, opening with a Greek (!) poem by Henri Estienne. ${ }^{58}$ Somewhat ironically Simon Stevin (1548-1620), a confirmed defender of the Dutch language who composed work on mathematics and engineering in French and Dutch received hardly any Dutch liminary poems, but did receive intricate poetry in Latin, French and Greek, apparently on the understanding that both Stevin himself and his public could read or at least appreciate it. ${ }^{59}$ As Casaubon's request for a Greek poem by Heinsius suggests, Latin is the default language but Greek has a higher status. Casaubon himself is a case in point, for in the great homage to Gruter in the Inscriptiones his poem is set apart from all the other poems, as the last item, on an otherwise empty page, in a larger font, directly preceding the text. And it is in Greek. ${ }^{60}$ Quite a few scholars such as Scaliger and Vulcanius contribute Greek poems, generally followed by a Latin translation in the same metre. This display of erudition and virtuosity in translating Greek into Latin or Latin into vernacular, honours the addressee

56 See above all Philip Ford's magnificent The Judgment of Palaemon. The Contest between Neo-Latin and Vernacular Poetry in Renaissance France (Leiden, 2013); the quotation (and preceding quasi-quotation) on p. 230 there. The conclusions of our research group on Neo-Latin and the vernacular reflected a.o. by the volume Dynamics of Neo-Latin and the Vernacular (see above n. 3) largely coincide with Ford's.

57 On Scriverius, see P. Tuynman, "Petrus Scriverius. 12 January 1576-30 April 166o", Quaerendo 7 (1977) 4-45 and S. Langereis, Geschiedenis als ambacht. Oudheidkunde in de Gouden Eeuw: Arnoldus Buchelius en Petrus Scriverius (Hilversum, 2001) and below.

$5^{8}$ See François Rigolot, "Paratextual Strategy and Sexual Politics: Louise Labé's Oeuvres lyonnaises, in Adrian Armstrong a.o. ed., Book and Text in France, 1400-16oo. Poetry on the page (Aldershot, 2007), pp. 163-75. In a poetical genre such as the tombeau multilingualism is more or less the rule, see Ford, The Judgment $127-58$.

59 In his Om de weeghconst, waterwicht, ende lochtwicght (Leiden, 1586) a poem in Latin and one in Greek by Ianus Grotius, in his Arithmétique (Leiden, 1585) three Latin ones from Baudius, Francis Bertie and Ianus Grotius, who also wrote a French poem.

6o Dousa's poem is put in a similar, but just somewhat less distinguished, position, apart from the rest, alone on the recto page of the privilege, in a larger font, preceding Casaubon's

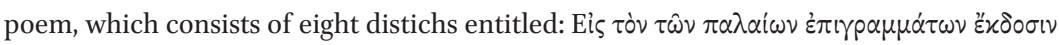

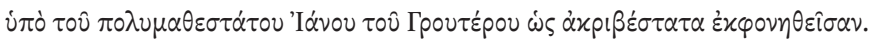


of the book, but it is most of all a playful demonstration of the authors' power over language. ${ }^{61}$

Besides a summary given by a friend, another function of the liminal poem is that of dedication by the author himself: Bonaventura Vulcanius opens his edition of Callimachus (1584) by his own dedicatory poem to Ianus Dousa, and only then follow several laudatory poems by friends; the second part of the book opens with a hendecasyllabic dedication to Iustus Lipsius. ${ }^{62}$ Many authors commence their books by poems of their own: in the earliest edition of Daniel Heinsius' poetry readers first came across a dedicatory poem by the author Divae Veneri pro elegiis suis, in Greek, thus underlining Heinsius' claim in the prose dedication that his (Latin) poetry was Greek in character because it was love poetry. ${ }^{63}$ The dedication of the Elegiae of Ianus Dousa (1586) consists of a short poem to a fellow diplomat drawn up by his son absente patre. There is no other paratext at the beginning apart from the title page. That, however, announces poems by Lipsius and others ${ }^{64}$ and the book does actually conclude with 31 poems addressed to Dousa. I shall return to this phenomenon below. Dousa's Annales, a historiographical work in verse largely composed by his son Ianus who died in 1596, is preceded by his own liminary dedication to the States of Holland, also in poetry: 'I who have sung the battles between William of Orange and the Spanish army, and the civil wars in my fatherland... now I begin a greater task, Ille ego qui Auriacas acies et Spanica signa / et patriae cecini civica bella meae... majus opus moveo. ${ }^{65}$ By his choice of words Dousa clearly presents himself from the outset as a second Vergil: the ille ego qui comes from the bracketed first lines of the Aeneid mentioned above, cecini is in the last line of Vergil's Georgics, and maius opus moveo is taken from the

61 Self-translation from Latin into the vernacular is rife in the liminary poetry for Pieter Bor (above), but also in many other genres such as tombeaux, album poetry etcetera.

62 Callimachi Cyrenaei hymni, epigrammata et fragmenta, quce exstant. Et separatim, Moschi Syracusii, et Bionis Smyrnaei idyllia (Leiden 1584), *2r-v and (following the new title-page of part 2) 2-3.

63 The poem follows directly on the prose dedication. On Heinsius' claim, see Harm-Jan van Dam, “Daniel Heinsius' Erstlingswerk: Prolegomena zu einer Edition der Monobiblos”, in Daniel Heinsius. Klassischer Philologe und Poet, ed. Eckart Lefèvre a.o. (Tübingen, 2007). pp. 171-189, 181-2 there.

64 Elegiarum libri II (Leiden, 1586). The "Elegiarum dedicatio" by Ianus Dousa filius, dated 29.III.1586, is to Franciscus Maelson of Enkhuizen. The title-page says: "Cum I. Lipsii aliorumque carminibus."

65 Annales rerum a Priscis Hollandiae comitibus per ccCXLVI annos gestarum ... Nunc primitus in unum metricae histioriae corpus redacti... (Leiden, 1599), pp. ${ }^{* * *}$ iiii r-[v r]. 
prologue to the second part of the Aeneid in Book Seven. ${ }^{66}$ Dousa's dedication is obviously a piece of self-promotion. This is underlined by his marginal notes to his own poem, which refer the reader to his earlier work, and also underlined by the next poem, an epigram addressed to the French Ambassador Buzanval with another reference to Vergil, this time to the Eclogues. ${ }^{67}$ At the same time, the allusions make a statement about Holland: the Aeneid is about the founding of the Roman people according to Jupiter's will: Dousa's Annales tell of God's purpose for Holland and the Dutch Republic. This example shows (again) that on the threshold the poet often directs his public while at the same time he (re)presents himself, often with the use of ancient intertexts that must be recognised to fully appreciate the work.

Dousa's poem is a case in point: liminary poems are not as superficial or as unimportant as one might suppose. In putting together his anthology of 'Belgian poets' Ianus Gruter included seven threshold poems by Vulcanius, who had never published a volume of verse. ${ }^{68}$ Petrus Scriverius edited Scaliger's poems after the latter's death with Encomia librorum, Scaliger's liminary poetry, as a second section. Apparently Scaliger kept a copy of all these poems because he thought them important. ${ }^{69}$ Scriverius also thought it worthwhile to make a handwritten improvement in a printed threshold poem by Vulcanius. ${ }^{70}$ That such poems were significant is clear also from their inclusion in other volumes of verse, as we shall see. Occasional poetry in general was much more appreciated in the early modern age than we may think, or even like: giver and recipient were sensitive to social status as expressed in texts and symbols and therefore such poems had better be good specimens. Some poems address a serious problem, such as Grotius' poem for Casaubon, which articulates his irenic ideas; or they may impress by powerful images, as in the long hexameter poem the theologian Jacobus Arminius composed for a volume of religious poetry, which opens with a compelling picture of storm and chaos ravaging the earth. ${ }^{71}$

\footnotetext{
66 See [Aeneis 1.1-4], Georgica 4.566, Aeneis 7.45.

67 Annales p. [v v]: Dousa has not written lentus in umbra $=$ Eclogues 1.1.

68 Rhanutius Gherus, Delitiae C. poetarum Belgicorum (Heidelberg, 1614), 562-72.

69 Iosephi Scaligeri Iul. Caes. F. Poemata omnia, ex museio Petri Scriverii (Leiden, 1615), 47-60.

70 It is the second poem by Vulcanius for Meursius' Poemata, where Scriverius in his own copy ("ex donatione auctoris. Sum Petri Scriverii") wrote at the line Utile consilium Zoile habeto, Crepa: "malim: do tibi Mome: crepa": the copy is on Google books, from an undisclosed library.

71 On Grotius' poem, see Van Oosterhout (see above n. 47). That by Arminius is in Balduinus Berlicomius, Hierostichon sive Carminum ex librius sacris et ecclesiasticis Metaphrasi Poetica concinnatorum Libri IX (Heidelberg, 1598).
} 
Another indication of the relative importance of threshold poetry is that, in spite of the frequency of some topoi, there is strikingly little overlap in the exact expression. Whereas many authors have a few ready-mades for inscribing in different Alba amicorum, here I have not come across any such doublets. At first sight it seemed that Scaliger was copy-pasting as seen in his poem for the edition of Lycophron by Meursius in 1597, and again two years later for the edition of Martianus Capella by Grotius: the first time it is vix egressus ephebi / vesticipes annos, et limina puberis aevi ("hardly beyond the toga-assuming years and the threshold of manhood"), and the next time: qui limina nondum tetigit puberis aevi / . . auspiciis noluit illis / Praeludere, quae vesticipum postulat aetas ("who did not yet touch the threshold of manhood... and did not want a tryout with those beginnings that the toga-assuming years demand"). The phrase is a conflation of passages from Ausonius and Statius. ${ }^{72}$ However, this use of the puer-senex-topos, young man and mature work, is most apt in both cases, for Meursius and Grotius were very precocious in producing an edition of an extremely difficult text. There is no laziness on Scaliger's part here: the connection he suggests between the two young men is appropriate. ${ }^{73}$

Liminary poets often take their cue from the very texts they introduce: all poems for Meursius' edition of the hermetic Lycophron are obscure and Petrus Bertius for instance used a whole range of rare archaic words in his nineteen lines. ${ }^{74}$ In liminary poetry for editions of ancient texts it is almost standard practice to compliment their editors for having cleaned their neglected or mistreated author. ${ }^{75}$ When applied to work on the Silvae of Statius, for instance ("Woods," around $95 \mathrm{AD}$ ), poets state that the editor gave the trees more room, chopped the undergrowth and let in the light, as William Barclay does: Silvas Papinii tenebricosas, / Quis ante ausus erat perambulare? / Totas horridula occupabat umbra... ${ }^{76}$ A good poet, such as Iustus Lipsius, added allusions to the poet and his work. Thus in his poem for Iohannes Bernartius' little commen-

72 Ausonius Protrepticon ad nepotem 73-5 "idem uesticipes...puberis aeui...ad mores ... produxi," Statius Silvae 2.1.38 "hinc anni stantes in limine vitae." Scaliger's poem for Grotius also alludes to Silvae 2.1.109.

73 Lycophron is reputedly the most obscure poet from antiquity and Martianus was characterised unforgettably by C.S. Lewis: "the universe, which has produced the bee-orchid and the giraffe, has produced nothing stranger than Martianus Capella" (The allegory of love (New York, 1963), 78).

74 musteus, querquerus, hispidus, nequiores quam nummi novi, praefiscine and more.

75 With terms such as foedus, squalidus, obscurus, nitidus, macula, tergere, putare, purgare, mundare and all their cognates.

76 In Ioh. Bernartius' 1599 commentary, 8 lines, 1-3, and also Petrus Zypeus at the end of the book, line 11: Splendidiora die tenebrosa cacumina reddit /. 
tary (1595) he says, quite rightly, that Statius is poeta summus, / Certe proximus est poeta summo, 'a sublime poet or at least a poet very close to the most sublime one'. In this way he alludes to the last lines of Statius' Thebaid, where Statius urges his book to follow the footsteps of the most sublime poet, Vergil: nec tu divinum Aeneida tempta / sed longe sequere et vestigia semper adora ("do not attempt to rival the divine Aeneid but follow at a distance and for ever reverence its footsteps."). ${ }^{77}$ And Lipsius ends with the certainty that, by way of thanks, Statius himself will put an oaken wreath on Bernaert's head (tuam ipse quercu / frontem Papinius libens coronat). This is a subtle allusion to Statius' own complaint that he had never won the oaken wreath that was the poet's prize in the Capitoline Games; but according to Lipsius, now Bernartius will. ${ }^{78}$ Punning on proper names is also frequent: the first name of Scaevola Sammarthanus (Scévole de Sainte-Marthe), meaning 'left-handed', gained him many poems playing with dexter and laevus. Lycophron, so Ioannes Bruno claims in his poem for Meursius' edition that is actually meant for Scaliger, repelled his readers by his name: Lycophron, from $\lambda$ úxos 'wolf'. Thanks to Scaliger's efforts as a textual critic he has now become Glycophron, from $\gamma \lambda u x u$ ' 'sweet'. ${ }^{79}$

\section{Liminary Poems as Literature}

One of the most interesting aspects of the liminary poem from a literary point of view is how it is frequently transposed to other surroundings, and by this means loses its liminal character and gains a new significance: by putting together all Scaliger's poems on books Petrus Scriverius combined them into a new system, and we read them, so to say, horizontally, comparing the books and Scaliger's skill in differentiating his poems, while in their original context we compared the various poems and poets within one book, on our way to the work itself. ${ }^{80}$ Heinsius wrote more than thirty Greek liminary poems for others and around ten for his own publications; together with his other Greek poems

\footnotetext{
77 Statius Thebais $12.816-7$.

78 Bernartius' 1595 edition has only a few notes. In Silvae $5 \cdot 3 \cdot 231-2$ Statius regrets not having won the Capitoline Games: "nam quod me mixta quercus non pressit oliva / et fugit speratus honos..."

79 "In Iosephum Scaligerum Lycophronis Interpretem \& Ioannem Meursium eiusdem illustratorem", in Meursius' 1597 edition, [+7v-8r].

8o We may see a parallel with Jakobson's paradigmatic and syntagmatic axes.
} 
they make up a separate section of his collected work, Poemata Graeca. ${ }^{81}$ It is here that his readers read them as items in a virtuoso performance of Greek poetry, disconnected from their original liminal use. A new context implies new titles as well, for a heading may be omitted in a threshold poem, or be given merely as Aliud or be too unspecific to be understood in a new context. ${ }^{82}$ The most drastic instance here may well be that of a threshold poem by Thomas More for the Hymni christiani by the blind court poet Bernard André (1517) entitled "Ten lines by Thomas More on the Hymns of Bernard André from Toulouse, royal poet". ${ }^{3}$ Eight months later the same epigram appeared among More's Epigrammata (1518) but now entitled, either by More or perhaps by his friend Erasmus: "On a Certain Person who Wrote Hymns on the Saints, Unlearnedly, Maintaining in his Preface that he Wrote them Ex Tempore and did not Keep to the Metrical Regularities, and that his Matter did not Admit Eloquence". To emphasize the reversal of intentions the poem was now sandwiched between two satirical poems. ${ }^{84}$ This is an exceptional example, but it is clear that new surroundings imply new titles and new interpretations.

The transfer of liminary poems to collected verse effects all kinds of shifts in meaning. When poets adopt threshold poems in their poemata collecta these are either their own compositions for the books of others or the poems they received from others. Each kind receives its own new context in collected verse: poetry by others gets a place in books of Adoptiva. Authors generally accommodate their own (laudatory) liminary poems among the occasional poetry, in sections called Silvae, Farrago, Epigrammata and similar titles implying diversity, not as one unit, but here and there. In these surroundings liminary poetry rubs shoulders with wedding poetry or album poetry or funerary poetry and, by its new position, enters into new relationships. These same poems no longer

81 Graeca et e Graecis versa, since the 1610 edition of Heinsius' Poemata (pp. $171 \mathrm{ff}$.), not all of them liminary poems.

82 Aliud: for instance Gevartius for Eust. Swartius' Analecta (see below), Scriverius for Gruter's Inscriptiones, Grotius for Meursius' Meditationes sacrae. When more liminary poems by the same poet are printed, they are often called "eiusdem.... Many liminary poems have only "ad (name)" as a heading. For wedding poetry changing its character when included in collected verse, see also my Taking occasion (see above n. 3), 105-6.

83 "In Hymnos Bernardi Andreae Tolosatis poetae regii, Thomae Mori Hexadecastichon."

84 "In quendam qui scripserat hymnos de divis parum docte, testatus in praefatione se ex tempore scripsisse nec servasse leges carminum, et argumentum non recipere eloquentiam": David R. Carlson, "Reputation and Duplicity: The Texts and Contexts of Thomas More's Epigram on Bernard André”, English Literary History 58 (1991), 261-81. On André, see also Gilbert Tournoy Humanistica Lovaniensia 27 (1978), pp. 45-7, and (also on the ambiguity of Erasmus' poem in the Hymni) Vredeveld (see above n.35) 49, 153, 234-5. 
introduce and lead over to something else but mainly advertise the scope of the poet's network. A second life in a volume of verse also offers extra immortality to the addressee. For that very reason a poet might decide to exclude a certain item, thus Grotius remarked about his own long and ambitious poem for Meursius: 'I will not have my iambic poem for the book De Gloria reprinted [in my Collected Verse], for I fear that glory chased in this way will escape us. ${ }^{85}$ When we take a closer look at Grotius' Poemata collecta (1616), we see that the long, ambitious poems on Bor's History and Dousa's Annales are included in Silvae liber II, in quo Patria, the long poem for Gruter's Inscriptiones early in his Farrago liber 1, an epigram for Bor's book in Epigrammata liber 1, two poems for Meursius in Farrago (one in 1 and one in 2), three others in Epigrammata liber 1, two of them separated by other poetry, one poem on Scaliger's Eusebius is in Farrago 3, one in Epigrammata 1; most liminary poems are in the Epigrammata, frequently interspersed with wedding poetry, poems on paintings, mottoes, contemporary events and other various matter. ${ }^{86}$ So what once was a liminal summary now becomes part of a patriotic program; thus two poems that once showed two different ways to introduce the same book now become separate and are perhaps surrounded by witty epigrams. All these rearrangements demand new interpretations from the reader.

If liminary poems are taken from their original place and included in volumes of collected verse, that does not always mean that the two versions are identical. Heinsius constantly revised and rearranged his poems; texts in the Poemata collecta often differ from the original threshold poem, either by the omission of couplets or by variation and, although there are few radical changes, this means that not only the context but also the poem itself has become different. ${ }^{87}$ Sometimes, in Heinsius and others, we find liminary poems that are missing in the books to which they refer. Most of these are in fact quasi-liminar, for they have one of two functions: either they accompanied a presentation copy, or they are meant as (implicit) thanks for such a gift, but

85 "Iambos in librum De Gloria recudi veto. Vereor enim ne illa nos hoc modo sectantes fugiat": Grotius Correspondence number 473, 25.vili.1616, 527-8.

86 The imprint of the volume is 1617 , but it is from 1616. The poems for Bor, Dousa and Gruter are on pages $46-55,60-2$ and $135^{-9}$, Meursius on $247-9,288-9,335^{-7}, 362-3$, Scaliger on 299-300, 344-4.

87 As for instance his poem for Baudius' Poemata 1607: lines 16-17 are missing in the poem in Heinsius' Poemata: Seu lepido mores alienos tangere socco / Materiem quis non se velit esse tibi? In the poem for Gruter's Plautus (1621) 7-8 Jamque suis potitur fruiturque beatum / laudibus et laudes astruit ipse suas became in Heinsius' poemata 1621 and 1640: Laudibus hic potiturque suis fruiturque beatus / sed tamen et laudes astruit ipse suas. Similar examples from Heinsius abound. 
they were not printed on the threshold of a book. Free copies for distributing to friends were the only kind of 'royalties' paid by publishers. When authors gave away a copy, they often composed a poem for these presentation books as well. It is a piece of luck if an inscribed copy survives, but their authors might also have published such poems. In Heinsius' Poemata there is a poem entitled Ad I. Scaligerum cum illi Silium Italicum offerret: a poem for Scaliger to accompany Heinsius' first publication, an edition of the Punica by Silius Italicus and some notes (1600-01). Both the edition and the notes are dedicated to Scaliger, the notes with a Greek poem and a long hexameter poem in Latin, not identical to the poem cum illi Silium offerret. ${ }^{88}$ The poem for a presentation copy is a special variety of the liminary poem, which we have left aside today. Genette distinguished between public dedication of a book, for instance by a dedicatory poem (dédier), that is a liminary poem, and private inscription of a copy (dédicacer), that is a presentation poem. The presentation poem is above all a dedication, but it also retains some of its liminal character, for one reader only. Such poems are in fact 'epitexts' according to Genette's system, a paratext not included in the book to which it belongs, in this case epitexts disguised as paratexts. By Heinsius' publication of this poem which had been meant for Scaliger only, private becomes public. This case seems to be somewhat exceptional: Grotius did not include his own presentation poems in his collected work. ${ }^{89}$ The poem appeared only in the first edition of Heinsius' poetry; in the next seven editions it is lacking.

Scaliger reacted to the presentation of Heinsius' Silius with an 'improvised' poem, ${ }^{90}$ and poems as thanks for presentation copies are not uncommon: Heinsius' own poem of thanks for the gift of Grotius' Adamus exul is in his Collected Verse and in that of Grotius as well. ${ }^{91}$ Poems such as these are often included in collected poetry. Together with the far greater number

88 Silius Italicus, De secundo bello Punico ... Notae... (Leiden, [1600-01]); this edition includes the Crepundia Siliana, the notes. The long hexameter poem is in Heinsius' Poemata under the title Pro Silio suo ad I. Scaligerum in the section Iambi, odae, epica et satyrica [Sylvae III; IV]. The presentation poem, of 34 lines, is Elegiae 2.2 in the 1603 edition of Heinsius' Poemata.

89 However, Heinsius also included his Ad Hugonem Grotium carmen cum ei Silium offerret in his Poemata 1603 (Iambi, odae, epica et satyrica number 6). Interestingly, this version and the one printed by Grotius in his own Poemata collecta (1616), 456, diverge on several points.

90 Danieli Heinsio gratiarum actio pro dedicatione Silii Italici. Ex tempore: Iosephi Scaligeri Poemata omnia (1615), 25 (outside the section Librorum encomia).

91 Four poems below the Silius poem to Grotius, and in Grotius' 1616 Poemata 457. 
of threshold poems which authors had received for their books they were adopted in so-called books of Adoptiva, separate sections in authors' Collected Verse, a practice introduced in Holland by Ianus Dousa, ${ }^{92}$ Other poetry written for the same author is included here as well, such as wedding poems, but the majority of poems in Adoptiva consists of liminary poetry by others. This practice is the exact mirror of the adoption of one's own poems for others into various sections of Collected Verse. It is not surprising that poets are less indulgent to their colleagues than to themselves: they include only a few of the liminary poems they received. Thus Heinsius omitted from his liber Adoptivus at least five poems out of the more than ten he received for his tragedy Auriacus. In the case of Adoptiva too the liminary poem loses most of its original functions: what had been a paratext has now become an epitext according to Genette, which enters into new relationships with other former threshold poems and occasional poems. The significance of these books of received poetry lies in the quality of the authors and of the poems collected there: Heinsius aptly subtitled his book In quo magnorum aliquot virorum ad autorem poemata.

\section{Final Example}

At the end of this paper, I wish to turn back from these reflections to one, concrete illustration, a threshold poem chosen from the poetry of Daniel Heinsius that opened this paper. This is no more than just a short indication or recapitulation of the kind of questions this liminary poetry may raise. The following poem by Heinsius is the first threshold liminary poem of five in the Analecta ("crumbs", "leftovers") of Eustathius Swartius, a young scholar from the Palatinate, who dedicated the book to his mecenas Iacob van Dijck. It is also found in Heinsius' Collected poems. ${ }^{93}$

92 See n. 65 above for Dousa's 1586 Elegiae. Pp. $75^{-10} 7$ bear $3^{1}$ poems addressed to Dousa by Lipsius and others, as the title-page had already announced.

93 Analectorum libri III: in quibus innumera auctorum, quà Graecorum quà Latinorum, loca emendantur (Leiden 1616), (.)(.) r-v, Heinsius Poemata 1621, 246 (not yet in the edition of 1617). On Swartius, see A.J. van der Aa, Biographisch Woordenboek der Nederlanden 17.2 (Haarlem 1874), 1109. From 1639-43 he was rector of the Latin schools in respectively 's-Hertogenbosch, Breda and Utrecht. 
In Eustathi Swartii Analecta inscripta viro Amplissimo \& omnium eruditorum fautori maximo, Iacobo van Diick, Regio Legato, Maecenati domestico (Title in Swartius' Analecta)

In Eustathi Swartii Analecta viro Ill. viro Iacobo Dyckio Legato Regio, domestico patrono, inscripta (Title in Heinsius' Poemata Collecta 1621) ${ }^{94}$

Qualis cum Lyciam maternaque deserit arva

Et Cyrrhae dominas visere Phoebus amat, Surrexere Deae. redeunt animusque vigorque

Et cunctae veniunt ad sua plectra manus. Haec parat heroos, numeros parat illa minores 5

In Venerem, tragicum tertia cantat opus.

Ille favet cunctis, meritamque ex ordine laurum

Dividit immunes nec sinit esse Deas,

Talis Hyperboreo postquam migravit ab axe

Dyckius inque sua vivere coepit humo 10

Occurrere viro Latiae Grajaeque Camoenae,

Et si quem Phoebi mysticus afflat amor.

Swartius hos inter, domino gratissimus autor,

Inscriptum curae fert melioris opus.

Ille suas vultu placido dignatur alumnas $\quad 15$

Et fovet et docta fertque probatque manu.
Like Apollo when he leaves Lycia, the land of his mother

and longs to see the mistresses of Delphi: the goddesses rose, their intellect, their energy return

and all hands reach for their plectra: one designs heroic verse, another one minor verse honouring Venus, a third one sounds a tragic work.

He favours them all and he distributes the deserved laurel to each of them, not wanting any goddess to go without,

Just so when Van Dijck returned from the Hyperborean region and began to live in his own country Latin and Greek Muses came towards him

and others whom Apollo's mystic love breathes upon.

Swartius is among them, an author beloved by his master and he bears a work of careful thought, dedicated to him.

He favours his nurslings with placid face, cherishes them, carrying them approvingly in his learned hand

94 These lines are lacking in the editions of the Poemata collecta. 
Talis Thuscus eques, talis Busbequius olim, Just so the Etruscan knight, so

Cum Pharia dictas a bove liquit aquas Busbequius once,

Implevere suis venturum laudibus orbem when he left the waters called after the

Et tota gaudent posteritate frui. ${ }^{94}$

Egyptian cow,

Regia res amor est Musarum, regia res est, filled the future world with their

Cum pereant reges sceptraque nolle glorious actions

mori. 20

and happily enjoy all posterity.

Aspice quid nostro Moecenas tempore Love for the Muses is a royal thing, a possit: royal thing it is,

Quas peperit Musas jam colit ista domus.

when kings and sceptres pass away, to refuse to die.

Behold what Maecenas can do in our time:

this house now honours the Muses it brought forth.

On one side is the poem in its original context. It is important for literary and social history, since it reveals a complicated network of patronage: the title alone makes clear that it is not Swartius who is important but his patron Iacob van Dijck, Amplissimo \& omnium eruditorum fautori maximo, ... Regio Legato, Maecenati domestico. Van Dijck (1567-1631), a prominent Dutch citizen from Haarlem, was the Swedish ambassador in The Hague and a patron of the arts. In other threshold poems for Swartius' Analecta the names of Ianus Rutgersius and Petrus Scriverius turn up repeatedly. Rutgers (1589-1625), a Dutch jurist and humanist who worked for the Swedish crown as well, on Van Dijck's recommendation, would become Heinsius' brother-in-law a year after this poem. His poetry and his philological notes enjoyed a certain reputation. ${ }^{95}$ Scriverius, a central figure in the Leiden humanist circle and Heinsius' oldest friend there, had introduced Heinsius to Van Dijck; a few months before he composed this poem for Swartius / Van Dijck, Heinsius had given a first reading of his (Dutch) Hymn on Jesus Christ in Van Dijck's town house in The Hague, where Swartius lived at the time, as he states in his extremely humble and effusive dedication to van Dijck. In 1616 too, Scriverius brought out a volume of Dutch poetry by Heinsius, allegedly without his knowledge, that is often considered as the 'real'

95 On Rutgers, van Dijck and the parts played by Scriverius, Heinsius and Grotius, see L.Ph. Rank a.o, Bacchus en Christus (Zwolle 1965), esp. 7-76, D. Hoek, Haags leven bij de inzet van de Gouden eeuw (Assen, 1966), 111-207, Arne Jönsson, Letters from Sir James Spens and Jan Rutgers (Stockholm 2007), 15-20, 231 ff., van Oosterhout (see above n. 47), 54-8, also n. 58 . 
starting point of Dutch vernacular renaissance poetry. Scriverius dedicated it to Van Dijck. In the same year of 1616 Van Dijck's father died, a prominent citizen of Haarlem, where Scriverius lived. Heinsius composed a poem for the occasion. At the time Ianus Rutgers was staying with his former teacher G.J. Vossius (1579-1647), then regent of the Leiden School of Divinity and occupied with the edition of Hugo Grotius' poemata collecta. Rutgers persistently 'pestered' Grotius in order to obtain a poem in this new prestigious work by a famous scholar and politician in order to 'immortalize' van Dijck. Finally Grotius gave in and inserted a poem on Van Dijck in his Poemata. We see once again that poems of praise were much in demand. We also notice the overlapping of networks of Holland-Sweden and Leiden University. And we realise that these three men, Heinsius, Rutgers and Van Dijck together are central to questions of Swedish-Dutch relations, of literary patronage, and of the tension between Neo-Latin and the vernacular as represented by Heinsius' poetry, a network that needs further exploration.

The original context as the first liminary poem in Swartius' book underlines the importance of the network and patronage: Heinsius' poem is a logical continuation to Swartius' prose dedication where Van Dijck is repeatedly addressed as Maecenas incomparabilis, see line 17 Thuscus eques $=21$ Moecenas. Swartius calls van Dijck patronus and even praesentius et augustius numen and mentions his vultus... majestas. Heinsius echoes this with domino (13) and vultu placido (15). The next liminary poem, by Scriverius, follows Heinsius by mentioning both Swartius and Van Dijck in the title and embroiders on the same themes, with Apollo and Maecenas combining them with Haarlem and Holland. The epigram addressed to Van Dijck added by Scriverius pictures Rutgers, Heinsius and Van Dijck in a convivial setting, 'producing' Analecta. Two relative outsiders close the series, Caspar von Barth (1587-1658), the prolific commentator of Statius and Claudian, and Caspar Gevartius (1593-1666), another commentator of Statius, later town-clerk of Antwerp. They both sing only of Swartius and his learned Analecta. So we may say that the liminary poems fulfil their liminal duty by leading the reader from van Dijck and poetry to Swartius and the book itself. Heinsius and Scriverius set the tone by confronting readers with a group of dedicated lovers of literature.

There are also the literary aspects to consider: the poem itself testifies to Heinsius' talent and erudition: its 22 lines skilfully combine praise of Van Dijck as a literary patron with a programmatic statement on the importance of poetry. The ambassador is like Apollo, leader of the Muses, who loves all their works and distributes laurel wreaths all around (7). The comparison of Van Dijck returning from Sweden with Apollo coming from Asia Minor is apt, for according to Greek historians the god was worshipped in the mythical land of 
the Hyperboreans identified with Sweden. In Holland Latin and Greek Muses, with their priests such as Swartius with his offering, come running to Van Dijck, their dominus. Van Dijck himself is compared not only to Maecenas, but also to the Flemish humanist and long-standing ambassador at the court of the Turkish Sultan Ogier Gisleen van Busbeke (1522-97) (line 17, the 'waters' refer to the Bosporus). The Turkish element refers back to Apollo, and Busbequius, like Van Dijck, was an ambassador-in his case of the Emperor Ferdinand I. Moreover, Busbequius also 'brought the Muses to Western Europe' by sending ancient manuscripts from Constantinople by the shipload. This leads to the emphatic praise of poetry at the end: she is queen, she never dies, although kings do. Love of the Muses is a royal thing regia res (19-20). But this also implies: love of the Muses and the immortality of poetry must be a matter of importance for Kings, such as Van Dijck's employer. The poem's epic, panegyric tone is obvious from its elaborate structure: Qualis (1)... Talis (9) ... Talis (17)). The predominant ancient inspiration is a passage in one of Claudian's Panegyrics; allusions to other ancient poets such as Vergil and Propertius occur. ${ }^{96}$ Here we recognise the serious and intertextual character of the liminary poem.

On the philological side we notice that the poem is transformed by its transfer to Heinsius' Poemata: its original title was more flowery, with its omnium eruditorum fautori maximo, which emphasized Van Dijck's central role among lovers of learning and literature. One distich, lines 19-20 in the original, is lacking in the Poemata. Whether by accident or on purpose, the result is, once again, somewhat more concise.

In its new setting the poem gets new overtones: it follows closely upon a poem for Heinsius' pregnant wife; since the couple married after the appearance of Swartius' Analecta, the order of the poems is clearly not chronological but based upon other principles: "Ad Ermegardiam Rutgersiam, Iani Rutgersi sororem unicam, suavissimam uxorem, cum primo esset gravida". ${ }^{97}$ The word mater occurs more than once in this poem; it is picked up by materna in the first line here, and this, together with the title makes us more aware of the web that unites Heinsius' wife, her brother Rutgersius and his master Van Dijck. In Heinsius' Poemata' the poem is followed by one in which Ianus Gruterus takes up residence with the Muses. This suggests that this famous scholar joins

96 Claudian Panegyricus de sexto consulatu Honorii Augusti 25 ff. "Cum pulcher Apollo / lustrat Hyperboreas Delphis cessantibus aras ... tunc (32)”. See also. e.g. Vergil Georgics 3.196 qualis Hyperboreis ... and 3.381 talis Hyperboreo, Propertius 3.1.3 ferre choros for fert alumnas (16).

97 Poemata $1621,244-5$. In the edition 1621 there is one poem between the two, a liminary poem for a theological work; this is omitted in later editions. 
Van Dijck in his Dutch home of the Muses, where Gruterus meets his fellow Palatian Swartius.

\section{Conclusion}

At the end of his poem Heinsius has brought us back to the house of the Muses, the book, which we entered at the beginning. I hope to have shown in this paper that liminary poetry comes in many shapes and hues: it may be a publisher's advertisement, an homage to the author of a book and at the same time self-presentation by its poet; or the dedication by the author of a book to a mecenas, which means expressing gratitude and boasting of one's relations. It is always an intermediary zone, where the reader can get used to the book and its author. Liminary poetry is an important, and appreciated, form of occasional poetry. Allusions to ancient texts are often significant for the interpretation. The authors and the addressees of liminary poems may include them in other volumes of poetry. According to the context where the reader meets the poem, the readers' interpretations must change, for the threshold poem is a many-sided genre.

Amsterdam, Vrije Universiteit 


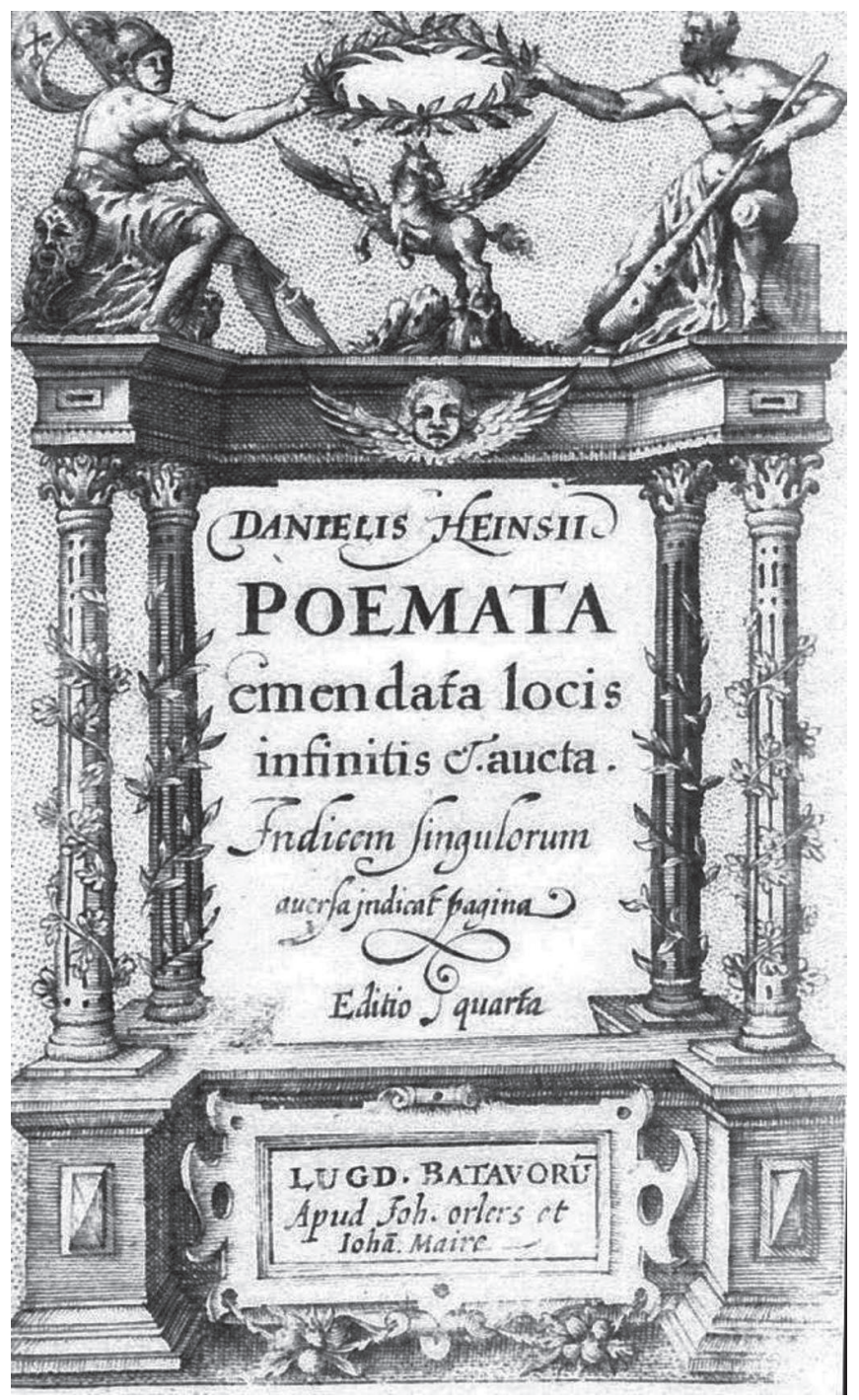

FIGURE 3.1 Daniel Heinsius Poemata collecta (Leiden 1613): Frontispiece 